\title{
Comparison of Digestibility of Some Bulky Feeds in Domestic Cattle and in its Crosses with European Bison
}

\author{
Kazimierz GAWĘCKI, Janusz KOZŁOWSKI \& Edward SUMINSKI
}

\begin{abstract}
Gawęcki K., Kozłowski J. \& Suminski E., 1986: Comparison of digestibility of some bulky feeds in domestic cattle and in its crosses with European bison. Acta theriol., 31, 23: 303-310 [With 5 Tables]

The digestibility coefficients of rations of green forage of grasses containing $37.6 \%$ dry matter and of maize silage with hay were determined in 5 bulls of Lowland Black and White breed and in 5 hybrids of cattle $\times$ European bison. The balance method was used. The initial live weight of hybrids was $400 \mathrm{~kg}$ and that of domestic cattle bulls $360 \mathrm{~kg}$ while their age was similar: $13-14$ months. The hybrids consumed $17.6 \mathrm{~kg}$ and cattle $14.4 \mathrm{~kg}$ green forage daily. In the second experiment they intook respectively $27.8 \mathrm{~kg}$ and $24 \mathrm{~kg}$ silage and about $2.5 \mathrm{~kg}$ grass hay daily. The coefficients of digestibility of green grass were significantly lower than those of the ration consisting of maize silage and hay. The hybrids digested feeds similarly as domestic cattle, though the digestibility coefficients in most cases appeared to be lower in cattle. The data illustrating changes in live weight in the animals during the experiments are included.

[Academy of Agriculture, Department of Animal Nutrition, 60-637 Poznań, Poland].
\end{abstract}

\section{INTRODUCTION}

In Poland for many years already the investigations have been carried out on crossing European bison with domestic cattle. It was found that the obtained hybrids distinguished by many positive traits. According to Krasinska (1969) the live weight gains in young hybrids in the first months after birth were higher than those in young Lowland Black and White cattle. The results of investigations of Szulc et al. (1971) showed high trimming percentage of the hybrid's carcasses. It was also stressed that their meat was palatable and contained less intramuscular fat. Some authors (Gębczyńska \& Krasińska 1972) observed in the European bison the ability of better utilization of less valuable bulky feeds, which may be of some economic importance. In view of these findings a tendency arose to exploit in production the advantages of the crasses of domestic cattle with European bison (Malecka \& Suminski 1976). The encouraging fact is the possibility of better utilization of feeds containing much crude fibre. The problem of digestibility in male calves of European bison and of cattle was studied by Szaniawski (1959). Peden et al. (1974) investigated digestibility of pasture herbs in different sea- 
sons in domestic cattle and in American bison. Gębczyńska et al. (1974) evaluated digestibility of nutrients in the rations of male European bisons and cattle.

In the available literature, however, there were no investigations described on digestibility of feeds in the crosses of these species. The preliminary results of investigations concerning this problem are presented in this paper. In the experiments described the feeds used were typical in feeding domestic cattle as well as European bisons.

\section{MATERIAL AND METHODS}

The investigations were carried out by the Chair of Animal Nutrition and Feed Management of the Academy of Agriculture in Poznan in cooperation with Poznan Unit of State Farms. The experimental part comprising 2 balance digestibility experiments was carried out in the farm Jeziory Wielkie. In each experiment the animal material included 10 males 13-14 months old, namely 5 bulls of Lowland Black and White breed and 5 hybrids obtained by crossing domestic cattle with European bison. Their dams were crosses Lowland Black and White $\times$ Charolais.

Table 1

Chemical composition of feeds $(\%)$

\begin{tabular}{lrrr}
\hline & $\begin{array}{c}\text { Mixture } \\
\text { of grasses }\end{array}$ & $\begin{array}{c}\text { Maize } \\
\text { silage }\end{array}$ & $\begin{array}{c}\text { Grass } \\
\text { hay }\end{array}$ \\
\hline Dry matter & 37.6 & 24.4 & 88.7 \\
Crude ash & 2.4 & 1.8 & 7.4 \\
Total protein & 4.6 & 2.4 & 12.7 \\
Crude fibre & 12.0 & 6.8 & 26.1 \\
Crue fat & 1.6 & 1.6 & 4.2 \\
N-free extract & 17.0 & 11.7 & 38.3 \\
\hline
\end{tabular}

At the start of the experiments the live weight of cattle bulls was about $360 \mathrm{~kg}$ and that of hybrids $400 \mathrm{~kg}$. The animals were kept in individual pens of area about $10 \mathrm{~m}^{2}$. Before the first experiment there was a 14 days initial period for adaptation and before the second this period lasted for 10 days. The animals had to get used to new environment, namely lodging, cowman care, management and feed. During this period also the amount of feed that the animals would be able to intake was established. In the first experiment they were given only grass mixture, a typical nurishment of the European bisons (Borowski \& Kossak 1972). The green forage given to the animals was from the second cutting and perennial rye-grass (Lolium perenne L.) dominated in this grass mixture. In the second experiment the authors investigated the digestibility of hay and ensiled maize which were bulky feeds often used as main fodder in feeding cattle. Maize was cut in the milk wax phase, the silage was of good quality and contained in fresh matter $1.47 \%$ lactic acid, $0.59 \%$ acetic acid and $0.11 \%$ butyric acid. On an average the hybrids intook $25-25.3 \mathrm{~kg}$ and the domestic cattle bulls 21.4- 
$-22.0 \mathrm{~kg}$ silage daily. The hay supplement amounted to $2.5 \mathrm{~kg}$ and $2.43 \mathrm{~kg}$ respectively. In the cattle ration dry matter hay constituted $29.1 \%$ and in that of hybrids $26.9 \%$. In the first experiment the domestic cattle consumed $14.4 \mathrm{~kg}$ and the hybrids $17.6 \mathrm{~kg}$ grass daily. The chemical composition of the feeds used in both experiments is presented in Table 1. The content of dry matter in grass was high $(37.6 \%)$ because the plants were cut in later phase of growth and, additionally because they were mowed in July and August during the summer drought. For this reason in the first experiment and due to hay supplement in the second there was no difficulty in collecting faeces. In both experiments the faeces were of compact but soft consistency. Digestibility was determined with balance method. Faeces were collected for 5 days. The chemical analyses of feed samples, feed remnants and of faeces were carried out with conventional methods in the chemical laboratory of the Chair of Animal Nutrition.

At the end of the experiments the mean live weight of the hybrids was $425 \mathrm{~kg}$ while that of domestic cattle bulls $341 \mathrm{~kg}$.

\section{RESULTS}

The hybrids of domestic cattle and European bison, though previousely they lived in half free environmental conditions, quickly got used to changed conditions, behaved quietly and accepted the man care. This tameness could be caused by the admixture of Charolais, a beef breed. Perhaps they adapted so easily because from the first months of their lives they were reared in small groups and often were in a direct contact with men. The Lowland Black and White bulls originated from a productive dairy herd and sometimes they were too excitable. The given feed was eaten by them willingly though in lower amounts than by hybrids (Table 2). In the second experiment the animals in individual groups consumed different amounts of silage and similar hay rations. This differentiation, however, as seen in Table 2, had insignificant effect on chemical composition of the rations consumed. Thus it could be stated that within each experiment the groups compared intook rations of almost identical chemical composition (Table 2).

The digestibility of individual components of grass was much lower than that of the ration consisting of maize silage and hay (Table 3 ). These differences in dry matter amounted to 14.9 and in total protein to 8.0 and were statistically highly significant. However, as concerns ability of digesting the tested feeds, there were no distinct differences between domestic cattle and hybrids. Only in the experiment with feeding silage and hay the digestibility in hybrids was higher by 0.3 $-3.5 \%$ in some individual components. In the case of $\mathrm{N}$-free extract this difference was statistically significant $(p \leqslant 0.05)$. In the remaining cases, except total protein, the differences were only close to statistically proved. In the experiment with feeding grasses the digestibility 
Table 2

Comparison of size and of chemical composition of the rations consumed by the animals.

\begin{tabular}{|c|c|c|c|c|c|c|c|}
\hline & $\begin{array}{c}\text { Daily } \\
\text { consumption }\end{array}$ & $\begin{array}{c}\text { Dry } \\
\text { matter }\end{array}$ & $\begin{array}{c}\text { Total } \\
\text { protein }\end{array}$ & $\begin{array}{l}\text { Crude } \\
\text { fibre }\end{array}$ & $\begin{array}{l}N \text {-free } \\
\text { extract }\end{array}$ & $\begin{array}{c}\text { Crude } \\
\text { fat }\end{array}$ & $\begin{array}{l}\text { Crude } \\
\text { ash }\end{array}$ \\
\hline & $\mathrm{kg} /$ day & \multicolumn{6}{|c|}{$\%$ of dry matter } \\
\hline \multicolumn{8}{|c|}{ Grasses } \\
\hline Domestic cattle & 14.4 & 37.6 & 12.2 & 32.0 & 45.2 & 4.4 & 6.3 \\
\hline \multicolumn{8}{|c|}{ Maize silage + hay } \\
\hline Domestic cattle & $\begin{array}{c}24.0 \\
(21.6+2.43)\end{array}$ & 30.9 & 11.3 & 28.1 & 47.4 & 6.2 & 7.0 \\
\hline Hybrids & $\begin{array}{c}27.8 \\
(25.2+2.54)\end{array}$ & 30.3 & 11.2 & 28.1 & 46.8 & 6.2 & 7.8 \\
\hline
\end{tabular}

coefficients were in general higher in hybrids, except those of fibre and crude fat. The variation coefficients did not exceed $10 \%$ which permitted to determine this experiment as well as that previousely discussed as very "sensitive" (Ruszczyc, 1978).

Basing on the results obtained in the experiments the authors calculated the nutritive values of $1 \mathrm{~kg}$ ration and consumption of dry matter, total protein and oat units per $1 \mathrm{~kg}$ live weight of the animals (Table 4). The nutritive value of the tested feeds calculated in oat units was only slightly higher in hybrids. In the first experiment it was 0.004 and in the second 0.010 which in relative values was respectively 1.5 and $3.3 \%$ in comparison with domestic cattle.

The daily consumption per $1 \mathrm{~kg}$ live weight of the animal was not proportional to the nutritive value of the rations (Table 4). The do-

Table 3

Digestibility coefficients - statistical evaluation.

\begin{tabular}{lcccccc}
\hline & $\begin{array}{c}\text { Dry } \\
\text { matter }\end{array}$ & $\begin{array}{c}\text { Organic } \\
\text { substance }\end{array}$ & $\begin{array}{c}\text { Total } \\
\text { protein }\end{array}$ & $\begin{array}{c}\text { Crude } \\
\text { fibre }\end{array}$ & $\begin{array}{c}\text { Crude } \\
\text { ash }\end{array}$ & $\begin{array}{c}\text { N-free } \\
\text { extract }\end{array}$ \\
\hline Domestic cattle & 57.5 & 59.3 & 58.2 & 62.0 & 50.3 & 58.2 \\
& 4.9 & 4.6 & 8.4 & 3.9 & 5.7 & 9.2 \\
Hybrids & 58.1 & 60.1 & 60.8 & 60.9 & 42.9 & 61.1 \\
& 7.0 & 5.6 & 6.9 & 6.3 & 9.7 & 6.1 \\
Domestic cattle & 71.4 & 73.0 & 66.2 & 73.8 & 67.9 & $74.5^{2}$ \\
Hybrids & 0.8 & 0.8 & 4.0 & 1.8 & 3.7 & 2.0 \\
& 73.0 & 74.8 & 66.5 & 76.3 & 70.1 & $76.5^{2}$ \\
& 2.3 & 2.2 & 4.3 & 2.9 & 4.6 & $1.0^{3}$ \\
\hline
\end{tabular}

${ }^{1}$ - The values below the digestibility coefficients are the coefficients of variation $(\%)$,

2 - Differences statistically significant $(p \leqslant 0.05)$. 
Table 4

Consumption indices and nutritive value of the rations.

\begin{tabular}{|c|c|c|c|c|c|c|}
\hline & \multicolumn{4}{|c|}{$\begin{array}{c}\text { Daily consumption per } 1 \mathrm{~kg} \text { live weight } \\
\text { of the animals }\end{array}$} & \multicolumn{2}{|c|}{ Contents in $1 \mathrm{~kg}$ ratior } \\
\hline & Dry & matter & Total protein & Oat units & $\begin{array}{l}\text { Total digesti- } \\
\text { ble protein }\end{array}$ & $\begin{array}{l}\text { Oat } \\
\text { units }\end{array}$ \\
\hline \multicolumn{7}{|c|}{ Grasses } \\
\hline $\begin{array}{l}\text { Domestic cattle } \\
\text { Hybrids }\end{array}$ & & $\begin{array}{l}15.2 \\
16.0\end{array}$ & $\begin{array}{l}1.8 \\
1.9\end{array}$ & $\begin{array}{l}0.011 \\
0.012\end{array}$ & $\begin{array}{l}26.6 \\
27.8\end{array}$ & $\begin{array}{l}0.267 \\
0.271\end{array}$ \\
\hline \multicolumn{7}{|c|}{ Maize silage thay } \\
\hline Domestic cattle & & 21.9 & 2.5 & 0.022 & 22.8 & 0.307 \\
\hline Hybrids & & 19.9 & 2.2 & 0.021 & 22.9 & 0.317 \\
\hline
\end{tabular}

mestic cattle consumed more hay and silage, namely feeds generally used in feeding them, while the hybrids intook more grass as it was the almost only feed of the European bison. Consumption of dry matter, total protein, oat units calculated per $1 \mathrm{~kg}$ animal live weight was lower in the first experiment than in the second. Thus surprising are data illustrating the changes in live weight of the animals during the experiments. As seen in Table 5 the live weight of hybrids increased, while in the domestic cattle it decreased during the digestibility tests.

Table 5

Changes in the live weight of the animals during the digestibility experiments $\mathrm{kg} / \mathrm{day} / \mathrm{head}$.

\begin{tabular}{lcc}
\hline & Experiment I & Experiment II \\
\hline Hybrids & 0.571 & 0.305 \\
Domestic cattle & -0.343 & -0.643 \\
\hline
\end{tabular}

\section{DISCUSSION}

The results of the experiments showed lower digestibility of grass mixture than of the ration composed of hay and maize silage. It depended on the kind of feeds and particularly on their chemical composition. The existence of correlation between chemical composition of feed and its digestibility was found in the investigations of Drożdż and Osiecki (1973), Drożdż (1979), Kowalczyk et al. (1976) and many others. Particularly important could be the content of crude fibre. In the grass ration its level was up to $32 \%$ of dry matter. High fibre content, about $30 \%$, was found in the faeces. It seems that this fact as well as higher in 
hybrids than in cattle consumption of dry matter may be the reason of a decrease of the coefficient of crude fat digestibility in hybrids (Ruszczyc, 1980). Difficult to explain is, however, lower digestibility of crude fibre in the hybrids found in this experiment. This difference was small and not proved statistically. In the second experiment also the difference in the values of coefficients of crude fibre digestibility between the groups compared was not statistically proved. In this experiment, however, the coefficient of digestibility of this component, as well as of the others, was higher in the hybrids (Table 3). The results obtained in our experiments seem to support those of Pytel (1969) on morphological structure of the alimentary tract in European bison. This author indicated the existence of some slight differences in the structure of this organ between European bison and domestic cattle, which were observable in rumen and were not perceptible in farther parts of the alimentary tract.

As mentioned already, the digestibility coefficients were in general slightly higher in the hybrids. In this respect the results of the investigations described differ from those of Gębczyńska et al. (1974) and in most parts from those of Richmond et al. (1977). In the former experiment the differences in the digestibility of the tested nutrients between European bison and domestic cattle ranged from 5.7 to $16.9 \%$. Richmond et al. (1977) carried out their investigations on one year old individuals of bison, yak and domestic cattle species. In cattle the coefficients of digestibility of hay from grasses and sedge were significantly lower while, in the contrary, the daily weight gains were the highest. A similar fact was observed in our investigations. In the second experiment the coefficients of digestibility of the ration consisting of hay and maize silage were significantly higher than in the first experiment and the changes in live weight of the animals did not correspond with them. It could be a result of the sensitivity of the ruminants to changes in feeds and, perhaps, of the relatively short initial period of adaptation. The change in feeds occurred when after feeding green forage the animals obtained the preserved feeds, namely silage and hay.

The digestibility coefficients in the hybrids were in most cases slightly higher. The changes in live weight during the experiment were more explicit. In the hybrids their live weight increased, while in domestic cattle it decreased. Probably it depended on the temperament of the experimental animals. The Lowland Black and White bulls were too sensitive while the hybrids behaved quietly being under the care of the same cowman.

Summing up it is possible to state that the experiments did not show 
the existence of more marked differences in the ability of digesting the tested bulky feeds between domestic cattle and its crosses with Europan bison. The results obtained as well as the observations and the data from the references indicate that these problems are much complicated and need further investigations.

\section{REFERENCES}

1. Borowski S. \& Kossak S., 1972: The natural food preferences of the European bison in seasons free of snow cover. Acta theriol., 17: 151-169.

2. Drożdż A. \& Osiecki A., 1973: Intake and digestibility of natural foods by roe-deer. Acta theriol., 18: 81-91.

3. Drożdż A., 1979: Seasonal intake and digestibility of natural foods by roe-deer. Acta theriol., 24: 137-170.

4. Gębczyńska Z. \& Krasińska M., 1972: Food preferences and requirements of the European bison. Acta theriol., 17: 105-117.

5. Gębczyńska Z., Kowalczyk J., Krasińska M. \& Ziołecka A., 1974: A comparison of the digestibility of nutrients by European bison and cattle. Acta theriol., 19: 283-289.

6. Kowalczyk J., Gębczyńska Z. \& Krasińska M., 1976: The digestibility of nutrients of natural diet by European bison in different seasons. Acta theriol., 21: $141-146$.

7. Krasińska M., 1969: The postnatal development of $F_{1}$ hybrids of the European bison and domestic cattle. Acta theriol., 14: 69-117.

8. Małecka G. \& Sumiński E., 1976: Zubronie - nowy rodzaj mięsa. Przegląd Hod., 7: 12-13.

9. Peden D. G., van Dyne G. M., Rice R. W., \& Hansen R. M., 1974: The trophic ecology of Bison bison on shortgrass plains. J. Appl. Ecol., 11: 489-498.

10. Pytel S. M., 1969: Morphology of digestive tract of the European bison. Acta theriol., 14: 349-402.

11. Richmond R. J., Hudson R. J. \& Christopherson R. J., 1977: Comparison of forage intake and digestibility by American bison, Yak and Cattle. Acta theriol., 22: 225-230.

12. Ruszczyc Z., 1980: Zywienie zwierząt i paszoznawstwo. Państw. Wyd. Roln. i Leśne: $1-475$ Warszawa.

13. Ruszczyc Z., 1978: Metodyka doświadczeń zootechnicznych. Państw. Wyd. Roln. i Leśne: $1-426$ Warszawa.

14. Szaniawski A., 1959: Comparison of digestibility of feedingstuffs with different protein rations for calves of domestic cattle and of bison, Bison bonasus. Acta theriol., 3: 318-319.

15. Szulc M., Tropiłło J. \& Krasińska M., 1971: Dressing percentage and utility value of the meat of European bison and domestic cattle hybrids. Acta. theriol., 16: 484-504.

Accepted, October 4, 1985. 
Kazimierz GAWĘCKI, Janusz KOZŁOWSKI i Edward SUMIÑSKI

\author{
POROWNANIE STRAWNOSCI NIEKTORYCH RODZAJOW PASZ \\ OBJĘTOSCIOWYCH U BYDEA DOMOWEGO I HYBRYDOW BYDEA \\ DOMOWEGO Z ZUBRAMI
}

Streszczenie

Na 5 mieszańcach bydła domowego i żubra oraz 5 byczkach rasy nizinno czarno-białej określano współczynniki strawności zielonki z traw o suchej masie $37.6 \%$ oraz kiszonki $z$ kukurydzy i siana (Tabela 1). Badania przeprowadzono metodą bilansową. Ciężar początkowy mieszańców wynosił $400 \mathrm{~kg}$, bydla $360 \mathrm{~kg}$ a wiek ich byl podobny i wynosił 13-14 miesięcy. Hybrydy pobierały dziennie $17,6 \mathrm{~kg}$ a bydło domowe $14,4 \mathrm{~kg}$ zielonki $\mathrm{z}$ traw. W drugim doświadczeniu zwierzęta pobieraly odpowiednio 27,8 i $24 \mathrm{~kg}$ kiszonki z kukurydzy oraz około $2,5 \mathrm{~kg}$ siana $\mathrm{z}$ traw (Tabela 2). Współczynniki strawności zielonek $\mathrm{z}$ traw byly istotnie niższe niż drugiej dawki składającej się z kiszonki z kukurydzy i siana. Hybrydy trawily zadawane pasze podobnie jak bydło domowe chociaż współczynniki strawności u bydła były w przeważającej mierze niższe (Tabela 3 ). 